apparently penetrates with good effect into every room in the house ; unfortunately the flue in the entrance hall is one which has a persistent down draught, and we are unable to warm the air in the hall and passages.

There appears to be no rule without exception for automatic ventilation; in one room we have Tobin's ventilators, the opening on the outside facing direct north; these have to be closed always when the room is occupied, as the cold air, after rising a short distance, descends on the heads of the occupants. In another room are four similar shafts built in the wall, the bottom inlets facing west; these shafts are always left full open in the severest weather, the draught being usually downwards and outwards; but why this occurs I cannot form the remotest conception, unless eddies are caused by an adjoining building. There is no doubt that external conditions affect the practical ventilation of any building, and no absolute rules are applicable in every case alike.

THOS. FLETCHER

Warrington

\section{Rain at Smyrna}

THE telegraph has informed us of a heavy fall of rain at Smyrna on Wednesday, November 25, but few particulars have yet reached us, except some from Capt. Stabb, Corr. Mem. Soc. of Arts. The storm began at six in the morning, and in a few hours 6 inches were registered. When the quay, or embankment, was proposed some years ago, in conjunction with the Council of Public Works I endeavoured to provide an efficient outfall sewer underneath it, but we were defeated by local intrigue. The drainage of Smyrna is worse than in the time of Strabo, by the large additions taken in from the shelving bay. The torrents pouring down from Mount Pagus (the Castle Hill) came through the Turkish quarter, causing the fall of some twenty houses, and washing bodies out of the Turkish and Jewish graveyards. On reaching the lower streets the sewers ceased to act, and cellars, stores, and warehouses were flooded, causing a loss of $50,000 l$. worth of opium, cotton, valonia, and other merchandise, and much damage to private houses. The River Meles overflowed its shallow beci, and reached the Point Railway Station, destroying some market gardens. In the suburb of Bournabat two houses were brought down, and the Cassuba railway embankment was damaged. The storm seems not to have reached beyond Manisa (Magnesia ad Sipylum), over Mount Sipylus, on one side, and Turbalu, beyond the Smyrna plain, on the other. No such inundation has taken place within memory. HYDE CLARKE

\section{The Sea-Mills at Argostoli}

WrTH reference to the inquiry of your correspondent, Surgeon Lloyd Thomas, in your issue of the Ioth instant (p. 129), there is a short paper on this subject by Capt. H. P. Shilston, entitled "On Curious Natural Phenomena in Cephalonia," to be found in the Transactions of the Liverpool Geological Association, vol. i. (Liverpool: Henry Young, I88I). The writer describes the inflow of water to the land through crevices in the limestone, as observed by him, and gives an explanation by Prof. Ansted, M.A., F.R.S., who considers that the phenomenon arises from the large amount of evaporation, within range of the district, by which the level of the subterranean stores of water is kept constantly below the level of the sea, notwithstanding the joint supply of rain- and sea-water.

U. W. J.

Liverponl, December 12

IN answer to the question of Mr. J. Lloyd Thomas in the las number of your valuable paper (p. I29) respecting the sea-mills of Argostoli, we beg to inform you that we have published, "Die Insel Kephalonia und die Meermühlen von Argostoli, Versuch einer Lösung dieses geophysikalischen Räthsels," von Prof. K. W. M. Wiebel, mit I Karte, 3 Skizzen und 5 Holzschnitten, 1873 .

Hamburg, December 12

\section{FRIEDERICHSEN AND CO.}

\section{Friction and Molecular Structure}

I SHALL feel obliged if you will kindly allow me to ask any reader of NATLRE whether moderate friction can so change the molecular structure of glass as to account for the following fact :Last night, about twenty minutes after a paraffine lamp had been lighted and had been burning steadily, its glass chimney suddenly burst into small fragments at the exact place at which, about an hour before, I had rubbed it with a piece of brown paper in order to remove soot from the interior. The chimney was thoroughly annealed, having been in constant use for more than three years. The flame was not high ; the night was not frosty ; the glass was uniformly thin at the place of fracture, which was six inches above the top of the flame, and two inches below the top of the chimney. The part which had not been rubbed is quite uninjured : not even a crack extending into it, while the rubbed part is shattered.

EDWARD GEOGHEGAN

Bardsea, December I

\section{The Resting Position of Oysters-A Correction}

Mr. J. T. Cunningham in his letter of November 28 (p. I29), after showing that Pecten opercularis must rest on its right valve, goes on to say:-Of Pecten maximus I cannot speak with certainty, and therefore leave to Mr. Arthur Hunt the responsibility of stating that there is a difference in respect of position in the two species." So far from my having hinted that any species of Pecten rests on other than the right valve, my letter, to which Mr. Cunningham refers, concludes with the plain statement, "in each case the mollusk rests on the same valve." The point to be noticed is that in Pecten maximus the right valve is most convex, and in Pecten opercularis the left valve.

A. R. HUNT

\section{Radiolaria}

I HAVE recently had the pleasure of finding, in the London Clay, a number of well-preserved specimens representative of several species of Radiolaria, most of which, I have good reason for thinking, differ from any known fossil or recent forms. It was my intention to submit them to the Geological Society during the present month, but circumstances prevent this being done. The delay may lead to an extension of the list, especially if $\mathrm{I}$ am fortunate enough to meet with a microscopist kind enough to assist in the examination of material yet untouched.

W. H. SHRUBSOLE

Sheerness-on-Sea, December I4

THE CONTINUITY OF THE GERM-PLASMA CONSIDERED AS THE BASIS OF A THEORY OF HEREDITY 1

THE thoughts developed in this most interesting and important essay were first expressed in a lecture delivered to students of the University of Jena last winter. They were reduced to writing in the spring, and completed for publication in June. The author received Oscar Hertwig's essay on the "Theory of Inheritance," and Kölliker's "On the importance of the Cell-nuclei for the Processes of Heredity," after his manuscript was complete. In the matter of the extreme importance of the nucleus he agrees with both these authors.

As was stated in reviewing here two years ago Prof. Weismann's memoir "On the Origin of the Sexual Cells of the Hydromedusæ," all his memoirs abound in original views and suggestions, which render them of peculiar and widely-spread interest. The present is no exception to the rule. It is intended in this article to give a kind of abstract of the memoir, composed largely of a series of translated passages : for the fuller development of details, the history of the development of ideas on the subject, and controversial matters, readers are referred to the original, which is an octavo of 122 pages.

"How is it," asks the author in commencement, "that in the case of all higher animals and plants, a single cell is able to separate itself from amongst the millions of most various kinds of which an organism is composed, and by division and complicated differentiation to reconstruct a new individual with marvellous likeness, unchanged in many cases even throughout whole geological periods?" The question is a hard one indeed, and the various attempts which have been made to solve it, I "Die Continuität des Keimplasma's als Grundlage einer Theorie der
Vererbung,"Von Dr. August Weismann, Professor in Freiburg i. B. (Jena: Verlag von Gustav Fischer, 1885.) 
though most useful as temporary advancements of speculation on the problem, such pre-eminently as Darwin's theory of pangenesis have failed hitherto to dispose of it satisfactorily. It is impossible now to believe that every cell of the organism can give off gemmules which exist at all times in all regions of the body, become collected in the generative cells, and are capable of becoming metamorphosed in regular order back again into the different cells of the organism.

The problem must be considered anew, and the present essay deals not with the entire subject of heredity, but with the fundamental question, How is it that a single cell of the body unites within itself the entire tendencies of inheritance of the whole organism? There are only two physiologically conceivable possibilities by which germ-cells endowed with such peculiar powers as we know them to possess can be produced. Either the substance of the parent germcell after passing through a cycle of changes required for the construction of a new individual possesses the capability of producing anew identical germ cells, or the germcells arise as far as their essential and characteristic substance is concerned, not at all out of the body of the individual, but direct from the parent germ-cell.

It is this latter view which Prof. Weismann holds to be correct, and maintains in the present essay, and which he terms the theory of the continuity of the Germ-plasma. On this theory heredity depends on the fact that a sub. stance of peculiar chemical and even more special molecular composition passes over from one generation to another. This is the "germ-plasma," the power of which to develope to a complicated organism depends on the extraordinary complication of its minutest structure. At every Ontogenesis a portion of the specific germ plasma which the parent egg cell contains is not used up in producing the offspring, but is reserved unchanged to produce the germ-cells of the following generation.

It is plain that this supposition reduces the question of heredity to one of growth. The germ-cells of all succeeding generations being merely pieces of the same substance as the first, and of the same molecular structure, when nourished under similar conditions, must run through a similar series of stages of development, and yield the same final products.

After combating objections which may be raised to the theory on the score of the heredity of "acquired modifications," it is pointed out that the germ-cells on it appear no longer as a product of the body, at least as far as their essential part, the germ-plasm, is concerned; they are rather to be regarded as something standing opposed to and separate from the entirety of cells composing the body, and the germ-cells of succeeding generations are related to one another as are a series of generations of unicellular organisms derived from one another by a continuous course of simple division into two.

Jager's and M. Nussbaum's views approached very near those of Weismann; but these authors inferred a continuity of the germ-cells themselves. Such a continuity of cells survives at present in but very few cases. In nearly all instances the generations of germ cells start from the parent, as very minute particles of germ-plasma only, to form, nevertheless, the basis of the germ cells of the next generation.

The author claims for his theory that even should it require to be abandoned in the future, it nevertheless represents a stage in our knowledge of the problem which must be passed through, which must be clearly stated and carefully worked out, whether the future prove it true or false. With this view of it he develops it in three chapters, the first of which deals with the conception of the germ-plasma.

THE GERM-PLASMA.-It now seems established that the only actual carrier of the tendency of heredity is the highly organised nuclear substance; fecundation consists in a union of nuclei ; the surrounding cell substance has no immediate participation in the result. E. van Beneden's splendid researches on Ascaris led far towards this conclusion in showing that the nucleus of the egg cell does not fuse in any irregular manner with that of the sperm cell, but that the nuclear loops of these two bodies arrange themselves opposite one another in regular order, two and two, and thus construct the new nucleus, the segmentation nucleus. Van Beneden, as is well known, viewed the two nuclei concerned as half nuclei male and female respectively, the union of which produced an entire nucleus of hermaphrodite nature. Weismann, on the other hand, speaks of "the union of the nuclear substance of the maternal and paternal individual." Strasburger has shown that in the fecundation of phanerogams the nucleus alone of the sperm cell (pollen tube), not the cell body also, enters the embryo sac to conjugate with the nucleus of the ovicell. Strasburger, led by Van Beneden's results, concluded that the occurrence of heredity depends on the transmission of a nuclear substance of specific molecular structure. This specific nucleo-plasma of the germ cell is what Weismann terms germ-plasma. This germ-plasma is, however, by no means identical with Nägeli's idioplasma. The idioplasma, according to Nägeli, is a network which stretches through the entire body, and in fact constitutes the specific molecular basis determining its manner of the body's existence. The general conception of a molecular basis of the organism governing its existence and opposed to the mere nutrient plasma is a fine and original one, and worthy of much merit, but in its detailed development Nägeli's theory cannot now be accepted. Even if the cell bodies are everywhere connected by fine outgrowths in all vegetable and animal pluricellular organisms, as recent research seems to show, the network present is one of nutrient plasma, not of idioplasma, for the determining molecular basis is confined to the nuclei which are not so connected. Moreover, there can be no one single substance such as idioplasma of identical composition permeating the whole body. On the other hand each different kind of cell in each organism must contain its specific kind of idioplasma, or rather nucleo-plasma regulating its peculiar mode of existence.

The author quite agrees with Strasburger in considering the "specific peculiarities of organisms as centred in the cell-nuclei," and also in many points in his statement that "from the nucleus issue forth molecular stimuli into the surrounding cytoplasma, which, on the one hand, govern the processes of change of material in the cells, and, on the other, give to the growth of the cytoplasma conditioned by the nutrition, a certain character peculiar to the species." A valuable confirmation of this position is afforded by A. Gruber's experiment on Infusoria, that, though artificially separated fragments of Infusoria without any portion of the nucleus can live for some time, they never are able to regenerate themselves, whereas fragments containing part of the nucleus always do so. The nature of the nucleo-plasma undergoes a regularly ordered series of changes during ontogeny. The simplest view to take is, that at each division of the nucleus the specific plasma of the nucleus divides itself into two halves, differing in their essential composition, so that each resulting cell-body also, its character being determined by the nucleus, becomes re-fashioned. Thus, in the case of any Metazoon, for example, the two first segmen tation spheres would undergo such change that the one would contain only the tendencies of heredity of the endoderm, and the other only those of the ectoderm, and so on throughout. Against such a supposition, however, stands the fact that is observed in instances of indirect division of nuclei during the process of kariokinesis, each mother nuclear loop of the nuclear plate splits exactly in two lengthways into two halves. Each daughter nucleus thus receives exactly the same supply of 
these, and it would appear as if the two nuclei could not differ, but must be exactly identical. Strasburger, therefore, considering this identity a fundamental fact, concludes that the difference between the two must arise subsequently to their separation as the effect of unlike nutrition. It is urged by Weismann, in antagonism to this view, which would be fatal to his theory, that all that is really proved by the fact is that at every division of a nucleus an equal mass of maternal and paternal nuclear substance passes to form each daughter nucleus, but that it is by no means shown that the quality of the parent nuclear plasma must be identical on both sides. On the other hand, from the effect of the daughter nuclei on their respective cellbodies, which are most commonly different both in size and texture, it seems proved that they are usually different in quality. As well-marked examples may be cited the polar vesicles. In the case of some Mollusca the egg gives off, by the indirect method of nuclear division, two polar vesicles, one after another, and each of these divides into two. The four polar vesicles perish, whilst the nucleus of the ovum remaining in the yolk combines with the sperm nucleus, and, making use of its own cell body, becomes the embryo. The reason for the difference here must be that the quality of the nucleus of the polar body is different from that of the ovicell.

In accordance with Nägeli's views, then, the molecular structure of the germ-plasma must be so much the more complicated the more complex the organism is which is to be developed out of it: and further, it can be stated that the nuclear substance must become successively less and less complicated as ontogeny proceeds, in proportion as the foundations which yet have to be evolved out of any cell and of which the nuclear plasma is the molecular expression, become gradually less in number. The general nucleo-plasma becorning thus gradually more and more simple in molecular structure, soon loses its capability of reproducing the entire organism; it cannot by any process be metamorphosed back again into the immensely complicated germ-plasma. Only the nucleo-plasma of the original segmentation nucleus is germ-plasma-that is, possesses the structure by the regulating action of which on the process of growth the entire organism can be evolved. In many cases, from the moment of the first division of the ovum into two blastomeres the one blastomere loses the power of reproducing the whole organism out of itself alone, since one resulting blastomere represents the future epiblast, the other the hypoblast. Somatic nucleo-plasma cannot become converted into germ-plasma.

Phylogenetically the germ cells did not originate at the termination of ontogeny, but at its commencement, as is well shown by the conditions existing amongst certain lower chlorophyll containing organisms such as Pandorina and Volvox. The phyletic origin of the first germ cells must evidently be sought amongst the earliest polycellular organisms differentiated by division of labour. In the genus Pandorina of the Volvocineæ no such division of labour has as yet arisen; each spherical colony is composed of exactly similar flagellate cells (each with an eyespot, chlorophyll contents and pulsatile vacuole) embedded in a common colourless jelly (homoplastide). These colonies reproduce themselves alternately by asexual and sexual process ; in the latter case the copulating individuals are not yet distinguishable from one another as male and female ; in either case every cell of the colony remains as yet a complete unicellular organism capable of separate reproduction. In Volvox, another genus of the same family, a heteroplastid condition has been attained and the separation into somatic and generative cells has been effected. The spherical colony consists of two sorts of cells-numerous small flagellate cells and much fewer large germ cells devoid of flagella. The latter alone can effect the production of a new Volvox sphere and can do this in two ways, either asexually (parthenogenetically) or after impregnation by small actively-moving spermatozoa formed out of certain of their own number. Now as Kirchner has shown, the germ cells become separated off from the somatic cells early in the segmentation of the volvox ovum before the escape of the young heteroplastid from the egg-coverings, which is exactly as should be according to Weismann's views.

Here is proof that there is no intervention of somatic cells in the course of growth between the parent germcell and the daughter germ-cells, but that the latter arise directly from the parent germ-cell, and thus the continuity of the germ plasma is established as a fact for the commencement of the phyletic development series. In later times, with increasing complexity of the organism, the time of the separation of the germ-cells became gradually more and more postponed in most cases, and at the present period often occurs quite late at the end of the entire ontogeny. If in the egg of Diptera the first two nuclei which separate themselves by division from the segmentation nucleus of the egg form the reproductive cells, this is a proof that they receive the entire germplasma of the segmentation nucleus unchanged.

There are, however, scarcely any theoretical grounds against the supposition that unmodified germ-plasma might be mingled with the nuclear substance of the somatic cells; on the other hand, it would appear a priori very conceivable that all somatic cells might contain some unmodified germ-plasma. The fact that a complete Begonia plant with fruit and fertile seed can be grown from a Begonia leaf, whilst in the case of many other plants no such result can be obtained, seems to show that in certain plants the cells, or perhaps only certain cells, of the leaf contain germ-plasma, whilst in others unchanged germ-plasma is not present in the leaves at all, or in very minute quantities only. In the case of the mosses, where almost every cell of the roots, leaves, and axial shoots can become a complete plant, probably all, or nearly all, the component cells must contain an adequate supply of germ-plasma.

The Meaning of the Polar Vesicles.-The egg-cell must contain two kinds of nucleo-plasma or idioplasma, namely, germ-plasma and histogenetic plasma. During its growth it has to accumulate yolk and to form surrounding membranes, in some cases to form a micropyle, and otherwise adapt its cell-body to the production of the future embryo. Therefore, besides the germ-plasm it carries, it requires another kind of specific nucleo-plasma just like every other histologically differentiated cell. This histogenetic plasma cannot be the same as that which subsequently governs the development of the embryo, and which arises from the infinitely complex germplasma. As soon as the egg is ripe for fertilisation it is necessary that the histogenetic plasma should be got rid of, in order to leave the germ-plasma free to act, and the extrusion of the polar bodies is the removal of this ovogenous nucleo-plasma. This is an entirely new theory as to the significance of the polar bodies, and directly opposed to all those which would see the extrusion of a male element in the act.

In the case of the male sperm-cell, also, two kinds of nucleo-plasma are present-germ-plasma and spermogenous nucleo-plasma. As soon as the spermatozoon is ripe, the spermogenous nucleo-plasma is cast off as the equivalent of the polar body. Strasburger has lately described a large number of instances amongst plants of different groups, in which processes resembling the extrusion of polar bodies accompany the ripening of the generative elements of both sexes. And it is probable that similar conditions will in time be discovered to exist in other plants.

On the Nature of Parthenogenesis.-The fact of the formation of the polar bodies, considered in the light of the theory of the sexuality of the germ cells, has been freely made use of to explain the occurrence of partheno- 
genesis. Balfour suggested "that the function of forming polar cells has been acquired by the ovum for the express purpose of preventing parthenogenesis." Weismann naturally cannot agree with this view, since he regards the extrusion of polar bodies merely as the removal of the ovogenous or spermogenous nucleo-plasma. At the time his memoir was written there were no instances in which it had been ascertained with absolute certainty whether polar vesicles areformed or not in the case of ova about to develop parthenogenetically; but in a postscript at the end of the memoir he is able to announce that he has discovered that in the case of parthenogenetic summer eggs of the Daphnidæ a polar vesicle of distinct cellular structure occurs. This is sufficient proof of the incorrectness of the older theory, and he further adduces the fact that in the case of the honey-bee the same identical egg can be made to develop either after fertilisation or parthenogenetically, according to the act of the queen, showing that the parthenogenetic and sexual eggs are of the same essential nature. The difference between the two must lie in the quantity of germ-plasma which they respectively contain. In order that the segmentation nucleus of the ovum may proceed to the process of ontogenesis, it must possess a certain mass. Even amongst higher vertebrates it is known that an unfertilised egg may occasionally go through the first few stages of segmentation, then, however, always failing through lack of the requisite power.

When impregnation takes place and the substance of the nucleus of the sperm-cell becomes added to that of the ovum, the combined mass of germ-plasm becomes powerful enough to carry through all the stages of ontogeny to the end. In the case of certain animals where the ovum remains unfertilised, and thus unchanged after the extrusion of the ovogenous nucleo-plasma, if a special supply of nourishment reaches its germ-plasma, this increases in amount by growth, and thus attains the mass requisite to start the ontogenetic process, with the result that parthenogenetical development takes place. In the ordinary sexual process it is the sudden doubling of the mass of the nucleus by the copulation that starts the segmentation of the ovum. It is the increase of the mass of the nucleus which gives the stimulus to segmentation, the disposition to which was already there before. The difference between eggs requiring fertilisation, and those not requiring it supervenes after the ripening of the egg and the extrusion of the ovogenous plasma. The phyletic inheritance of the capability of parthenogenetic development rests on a modification of the power of growth of the egg nucleus.

More than ten years ago Weismann expressed the conviction that "the physiological value of the spermcell and egg cell are identical," and now that the body of the egg cell can hardly have ascribed to it a higher value than that of a common nutrient ground for the two nuclei during the act of impregnation, this position seems a very secure one, Strasburger fully agrees, and states that "Sperm-nucleus and egg-nucleus do not differ in their nature." If it were possible to introduce by artificial means into any egg, immediately after the change of the germinal vesicle into the egg-nucleus, the egg-nucleus of another egg of the same species, it is probable that the two nuclei would copulate just as if a ripe sperm-nucleus had penetrated into the egg in the usual way, and a direct proof would thus be given that the egg and sperm-nucleus are in fact identical. The technical difficulties are too formidable to permit of this experiment being made, but a partial confirmation is afforded by Von Berthold's discovery that in certain algæ Ectocarpus and Scytosiphon, not only a female, but also a male parthenogenesis occurs. Further, the occurrence of conjugation must be regarded as a proof of the correctness of this view. There can scarcely be any further doubt that conjugation is the sexual reproduction of unicellular organisms. Amongst these usually the two conjugating cells are externally absolutely alike, and probably they are so internally also, but there are some low forms, such as Volvox, where a difference between the two is already fully established, huge egg shells and minute zoosperms being produced. The identity of the sperm nucleus and egg nucleus here insisted on only regards their essential fundamental structure and composition; each is in certain finer details necessarily peculiar, as transmitting the idiosyncracies of its own parent stock.

H. N. MOSELEY

\section{THOMAS ANDREWS, F.R.S.}

R. ANDREWS, whose death we announced a fortnight ago, was a native of Belfast (born December 19, 1813), and spent his whole life there. His father was a linen-merchant, in good position; and he received his early education at the Academy and at the Royal Academical Institution of Belfast. Thence he went to Glasgow, where he studied under Dr. Thomas Thomson, the well-known Professor of Chemistry, and learned pract:cal work in his laboratory. He had, next, a successful undergraduate career in Trinity College, Dublin; where he distinguished himself in Classics as well as in Science. Having spent some time in Paris, in the laboratory of Dumas; and having obtained his Medical Degree in the University of Edinburgh, in 1835 ; he devoted himself to medical practice in his native town. In this he was highly successful ; but he continued to devote his leisure, small as it was, to scientific research ; publishing numerous papers on chemical and physical subjects. To these we will recur, but it is noteworthy that in 1844 he received one of the Royal Medals, in the gift of the Royal Society, for his purely scientific discoveries, before he finally gave up professional practice. $\mathrm{He}$ was the first lecturer appointed to teach Chemistry in the Royal Belfast Academical Institution, and he resigned this post, as well as gave up practice, when appointed in 1845 to the VicePresidentship of the "Northern College," now Queen's College, Belfast. The Presidents and Vice-Presidents of these new Irish institutions were appointed some years before the Colleges were opened, or the Professors elected, in order that the Government might have their advice and assistance in maturing the whole scheme. Andrews was thus associated with another justly-distinguished Irishman, Sir Robert Kane; and it is mainly to their labours and foresight that the Queen's Colleges, when at last opened, appeared before the world in full working order.

It had been understood from the first that Andrews was to be the Professor of Chemistry in Belfast; but, when the time for appointing Professors arrived, he was required (as a matter of form, merely) to produce a few Testimonials. These he obtained at once, in the highest terms, from such men as Thomas Graham, Humphrey Lloyd, MacCullagh, \&c., and they need not be given here. But it may be interesting to show, as briefly as possible, the opinions of two of the greatest of foreign chemists. Liebig wrote (November IO, I845) as follows:- "Ich hege die volle Ueberzeugung dass der Platz um den Sie sich ... bewerben, keinen würdigern Besitzer finden dürfte. Sie haben viele Jahre hindurch mit den grössten Schwierigkeiten zu kämpfen gehabt, um der warmen Neigung welche Sie für die Naturwissenschaften hegen Nahrung zu geben, und weit entfernt dass Ihr Muth und Eifer dadurch gelähmt worden wäre, haben Sie durch Ihre letzten wichtigen Arbeiten über die Wärme bey chemischen Verbindungen dargethan, dass die Beschäftigung mit der Wissenschaft ein Bedürnniss ihres Geistes ist." Dumas (November 29, 1845) wrote :- "Vos titres à la nouvelle fonction à laquelle vous aspirez sont si clairs et si évidents que je ne concevrais guère que vous n'y fussiez point appelé . . . mais, tout en enseignant la chimie, n'oubliez pas que vous comptez au nombre des physiciens 